\title{
Resourcefulness Development in Entrepreneurship Program to Improve Resilience of Disabled Students At "Yakut" Special School Type C-C1 Purwokerto
}

\author{
Alief Budiyono ${ }^{1^{*}}$ \\ ${ }^{1}$ UIN Prof. K.H. Saifuddin Zubri Purwokerto \\ Corresponding Author: ${ }^{1}$ alief@uinsaizu.ac.id
}

Article History:

\section{Abstract}

Submit:

2022-01-02

Publish:

2022-03-04

Children with special needs or special health care needs (e.g., Down syndrome (DS), autism spectrum disorder (ASD), and cerebral palsy (CP)) are considered special because they require, in most cases, extraordinary longterm care in the hope of meeting developmental needs. In this regard, there is a systemic perspective of resilience in the ecology and development context, pursuing to identify for individuals to cope with persistent stresses. Based on this problem, "YAKUT"Special School type C-CI Purwokerto conducted a resourcefulness development program for mentally disabled students at "YAKUT" Special School type C-CI Purwokerto to increase the resilience of these students. In this study, the researcher used a qualitative type of research. The data collection process was carried out through observations at Yakut" Special School type C-CI Purwokerto, held from November to December 2021, and interviews with teachers at "YAKUT" Special School type C-CI. The entrepreneurial program programmed by "YAKUT" Special School type C-CI Purwokerto aims to help students remain competitive in the community. Students are trained to be tough and adapt to their limitations in this situation. Students who have resilience are willing to work hard to achieve their goals, adapt to changes to take advantage of new situations, and learn from their mistakes.

Keywords: Entrepreneurship, Resilience, Mentally Disabled Students 
Journal Homepage http://ijssr.net/index.php/ijssr

This is an Open Access article under the CC BY SA license

https://creativecommons.org/licenses/by-sa/4.0/

Published by Indonesian Academy of Social and Religious Research

\section{Introduction}

A systemic perspective of resilience in an ecological and developmental context aims to identify the elements that enable individuals to cope with persistent stresses. Although no definite term or variable defines resilience, several studies have examined various terms associated with resilience, such as a sense of mastery, optimism, and dependence on God. Resilience is also related to successful adjustment in terms of self-esteem, social support, various aspects of social life, problem-solving and coping strategies, and understanding of social integration, interdependence, and close relationships. ${ }^{1}$ Another study on resilience revealed three constitutional factors that include measures of self-efficacy, a well-defined faith life, and the ability to reframe obstacles. ${ }^{2}$

Interest in resilience as an observable concept and phenomenon emerged simultaneously but independently in ecology. Resilience can be broadly defined as the capacity of a dynamic system to adapt to disturbances that threaten the system s functioning, survival, or development. This concept can be applied to various systems that interact with each other, both living and non-living, such as microorganisms, children, families, security systems, economies, forests, or the global climate. The word resilience itself is rooted in the Latin verb resilire. Many disciplines have adopted this concept concerned with how well complex systems anticipate, adapt, recover, and learn in the context of major threats, surprises, and disasters. In this case, the research is focused on children with special needs.

Children with special needs or special health care needs (e.g., Down syndrome (DS), autism spectrum disorder (ASD), and cerebral palsy (CP)) are considered special because they require, in most cases, long-term special care in the hope of meeting developmental needs. Children with special needs are involved in a three-way interaction between children who experience dysfunction,

1 Beni Azwar, Deri Wanto, and Rahmad Hidayat, "Improving Self-Resilience in Students with Special Needs through the Counseling Teachers' Roles: A Case Study on Grounded Theory," Education Research International 2021 (2021), https://doi.org/10.1155/2021/7872889.

2 Putri Pranindita Sari and Yulia Ayriza, "The Relationship Of Parenting Self-Efficacy As A Predictor Of Resilience To Parents Of Children With Special Needs In Inclusive Schools," Advances In Social Science, Education And Humanities Research 296 (2019): 29-32. 
affected families, and the external environment in which the disability manifests. The crisis brought on by the first hint or diagnosis that something is going wrong with their child is perhaps the most difficult and shocking experience for parents.

The number of children with special needs, which tends to increase from time to time, is not followed by an increase in public knowledge and understanding of the characteristics of their development. Therefore, society (including parents) often gives inappropriate treatment, preventing children with special needs from developing their potential and abilities. These children face a variety of negative behaviours ranging from implied avoidance explicit rejection to cruel attitudes and behaviours. This phenomenon that sometimes also occurs in the school environment adds to children's risk factors with special needs.

In many cases, parents' initial reaction tends to be negative. ${ }^{3}$ Families either adapt flexibly and mobilize into effective action or freeze in varying degrees rigid, ineffective reactions, whereas others tend to reject or even deny the diagnosis itself. ${ }^{4}$ The Bower and Hayes study findings show that families without children with disabilities, families with children with intellectual disabilities, and families with children with physical disabilities are more characterized by similarities than differences. ${ }^{5}$ Changes in living routines are required to provide child care, which has been found to have a significant effect on family functioning. ${ }^{6}$ Difficulties faced by parents in dealing with children with disabilities and their family relationships were cited as a source of anxiety, overprotection, rigidity, and explanations for lower levels of coherence, less emphasis on the personal growth of other family members, and greater emphasis on control in the family. ${ }^{7}$ This difficulty indicates that parents of children with disabilities experience greater stress and more parenting challenges, such as more health problems, greater

3 Wylen Djap et al., "The Resilience of Single Mothers with Special Needs Children in Supporting Their Education and Fulfilling Their Needs During The COVID-19 Pandemic," IJDS: Indonesian Journal of Disability Studies 8, no. 2 (2021): 425-41, https://doi.org/10.21776/ub.ijds.2021.008.02.10.

4 Suneh Reza Zadeh et al., "Effectiveness of Positive Psychology on Hope and Resilience in Mothers with Mentally Retarded Children," Iranian Journal of Psychiatric Nursing 6, no. 3 (2018): 32-38.

5 Sari and Ayriza, "The Relationship Of Parenting Self-Efficacy As A Predictor Of Resilience To Parents Of Children With Special Needs In Inclusive Schools."

6 Radhika Mohan and Mrinmoyi Kulkarni, "Resilience in Parents of Children with Intellectual Disabilities," Psychology and Developing Societies 30, no. 1 (2018): 19-43, https://doi. org/10.1177/0971333617747321.

7 Zhila Fereidouni et al., "A Comparative Study on the Quality of Life and Resilience of Mothers with Disabled and Neurotypically Developing Children in Iran," Heliyon 7, no. 6 (2021): e07285, https:// doi.org/10.1016/j.heliyon.2021.e07285. 
feelings of restriction, and higher levels of parental depression than parents of children who are not disabled.

Raising a child with special needs or disabilities is associated with several negative outcomes, including stress, depression, financial difficulties, and stigma. In one study, approximately $41.2 \%$ of parents reported extreme psychological distress exacerbated by difficulties in managing their children's behaviour and increased perceived burden. ${ }^{8}$ This negative emotional response is more pronounced in mothers than fathers because often, mothers take on the main nurturing role. In some cases, the burden was differentiated around the type of disability, with parents caring for children with autism being more susceptible to distress than parents raising children with other disorders.

The reasons for this striking difference include the peculiar behavioural problems exhibited by children with autism spectrum disorders. ${ }^{9}$ Amid these struggles and emotional turmoil, some parents have emerged stronger by using adaptive coping and protective resources such as religiosity, spirituality, hope, optimism, and social support. Proponents of welfare research have emphasized the buffering role of social support against the deleterious effects of distress. The impact of social support in reducing stress and increasing well-being cannot be overemphasized. ${ }^{10}$ Support from social relationships can come from co-workers, family, neighbours, friends, or other important people. In addition, a distinction has been made between types of social support.

Families with children with special needs face normal stresses and tensions in family life and, in addition, adjustment to the presence of children with disabilities (Zadeh et al., 2018). Despite the many challenges associated with raising a child with special needs, accumulating evidence suggests that parents sometimes cope with their burdens with the availability of protective resources and coping strategies. Such families usually need help to reorganize their lives towards positive adaptation.

Although family resilience has not been studied directly in the field of disability, there is increasing evidence that families of children with disabilities exhibit a great degree of power, articulating the positive contribution of disability

8 Lisa C Melody-Mackey, "Adverse Childhood Experiences, Special Education, and the Role of Resilience in the Life Course" (Fielding Graduate University, 2021).

9 Fereidouni et al., "A Comparative Study on the Quality of Life and Resilience of Mothers with Disabled and Neurotypically Developing Children in Iran."

10 Jonathan Joseph and J Allister McGregor, Wellbeing, Resilience and Sustainability (Springer, 2019), https://doi.org/10.1007/978-3-030-32307-3_3. 
to their family life and well-being. ${ }^{11}$ Resilience for families of children with disabilities has been viewed either as an interaction of two groups of risk and protective factors (Rutter) or as a flexible process that demonstrates family strengths at different points during the family life cycle and under different circumstances (Walsh). ${ }^{12}$ This latter approach considers a family tough when it shows strength, even if it may not exhibit the same attributes at other times (Walsh). Several key factors that contribute to a strong family are: 1) interpreting difficulties, 2) building the potential of strengths, and 3) aspects of spirituality. In addition, for a family to bounce back in the face of challenging situations, it needs to have certain organizational qualities, such as flexibility, connectedness, communication, and the ability to utilize resources.

Masten has revealed that individuals who experience stressful life events and can cope with them to maintain a high level of well-being are known as resilient (Hove \& Rosenbaum, 2018). Masten defines resilience as a person>s dynamic ability to successfully adapt despite threats to survival, function, or development. Developing resilience requires social support, optimism, religiosity, and spirituality. Resilience and its relationship to well-being among parents of children with special needs have been explored previously. A recent study on mothers of children with ASD and other disorders reported that maternal resilience positively correlates with well-being outcomes. ${ }^{13}$ Merin also found that parental psychological resilience of children with ASD was protected from the high levels of depression and anxiety associated with high daily parental stress levels. ${ }^{14}$ Thus, resilience can be a good source of well-being among parents.

Entrepreneurship is a field of endeavor characterized by stress and hardship, if not also in some cases trauma. Thus, an understanding of resilience becomes a priority if scholars want to help entrepreneurs benefit the wider community. In this study, resilience at the individual level is an interesting phenomenon. Individual-level resilience is a prominent latent construct in the research context of children and adolescents with good developmental outcomes despite their highrisk status. Therefore, in this study, the researcher will discuss the development

11 Femke Scheffers, Xavier Moonen, and Eveline van Vugt, "External Sources Promoting Resilience in Adults with Intellectual Disabilities: A Systematic Literature Review," Journal of Intellectual Disabilities, 2020, 1744629520961942, https://doi.org/10.1177/1744629520961942.

12 Scheffers, Moonen, and van Vugt.

13 Mohan and Kulkarni, "Resilience in Parents of Children with Intellectual Disabilities."

14 Anugraha Merin Rajan, G Srikrishna, and J Romate, "Resilience and Locus of Control of Parents Having a Child with Intellectual Disability," Journal of Developmental and Physical Disabilities 30, no. 3 (2018): 297-306, https://doi.org/10.1007/s10882-018-9586-0. 
of resourcefulness in the entrepreneurship program to increase the resilience of mentally disabled students at "YAKUT" Special School type C-CI Purwokerto.

\section{Research Methods}

In this study, the researcher used a qualitative type of research. Moleong defines qualitative research as research that provides data results in the form of words that are found both written and oral data sourced from the subject and object under study. ${ }^{15}$ The qualitative approach used by the researcher is descriptive. The descriptive approach in this study describes various phenomena or events that emerge in the environment, both natural and non-natural. ${ }^{16}$ The data collection process was carried out through observations at "YAKUT" Special School type C-CI Purwokerto, held from November to December 2021 and interviews with teachers at "YAKUT" Special School type C-CI Purwokerto, specifically Drs. Rubimanto, M.Pd., Humam, S.Pd., Siti Marchamah, S.Pd., Muhammad Saidi, S.Pd., Suryani, S.Pd. At the same time, the secondary data sources used in this research are literature materials in books, theses, journals, and Entrepreneurship Program Plans for "YAKUT” Special School type C-CI Purwokerto Students.

\section{Result and Discussion}

\subsection{YAKUT Special School Type C and C1 Purwokerto}

"YAKUT" Special School Type C and C1 Purwokerto is a special school located on J1. Pahlawan Gang VIII Tanjung, South Purwokerto, Banyumas Region, Central Java Province. This special school was established under the auspices of the Tama Welfare Foundation or abbreviated as YAKUT, founded on June 2, 1961, and ratified by Notary Deed No. 14 dated August 10, 1961, by Notary Raden Mas Wiranto in Yogyakarta. "YAKUT" Special School Type C and $\mathrm{C} 1$ Purwokerto handle children with special needs such as mentally disabled children and autistic children initiating from the special school for kindergarten, elementary, junior high school, and high school level.

The vision of "YAKUT" Special School Type C and C1 Purwokerto is Optimal Development, Noble Morals, Skilled, Independent, and Faithful. and the Mission of the Special Schools Type C and C1 Purwokerto, specifically:

15 M Askari Zakariah, Vivi Afriani, and K H M Zakariah, Metodologi Penelitian Kuantitatif, Kualitatif, Action Research, Research and Development ( $R$ and D). (Yayasan Pondok Pesantren Al Mawaddah Warrahmah Kolaka, 2020).

16 Anggito Albi and Johan Setiawan, "Metodologi Penelitian Kualitatif," Sukabumi: CV Jejak 245 (2018). 

1) Providing educational services according to the talents and potential of students.
2) Implementing learning oriented to Student Independence.
3) Improving the culture of worship to realize Student Faith.
4) Improve human resource professionals to commit to their duties.

\subsection{Entrepreneurship and Resilience for "YAKUT" Special School Type C and C1 Purwokerto Students}

The term "child with special needs" is used to describe children whose physical, mental, or behavioural performance deviates from their normal condition, either higher or lower, such as children with mental retardation, learning disabilities, hearing impairment, visual impairment, physical disabilities, speech and language disorders, emotional and behavioural disorders, as well as those who are gifted. ${ }^{17}$ They are called children with special needs because of their condition, and they may require special or additional educational, social, or medical services to compensate for their academic, physical, and behavioural characteristics that differ substantially from what is considered normal. ${ }^{18}$

Children with special needs in living their lives require the ability to live their daily lives amid their limitations, in this case, resilience. In other words, resilience is characterized as proceeding to a higher level of functioning after a stressful experience amid limitations. ${ }^{19}$ This perspective emphasizes that individuals can generate further meaning in traumatic experiences and achieve well-being than simply coping with situations. According to the second approach, resilience is a trait characterized as resistance to being crushed by trauma or the competence to come back and recover from trauma and the forces of disaster. This approach accepts resilience as a trait that a person needs to survive. The approach raises several issues that emphasize resilience as an ability or trait.

Drs. Rubimanto, M.Pd and Humam, S.Pd stated that it is necessary to have a program to develop resources or qualified resources for mentally disabled students

17 Bibian Bibeca Bumbila García et al., "Characterization of Auditory Disability and Its Relation to the Resilience," International Research Journal of Management, IT and Social Sciences 5, no. 2 (2018): 15-22.

18 Maria Cristina Ginevra et al., "Career Adaptability, Resilience, and Life Satisfaction: A Mediational Analysis in a Sample of Parents of Children with Mild Intellectual Disability," Journal of Intellectual E Developmental Disability 43, no. 4 (2018): 473-82, https://doi.org/10.3109/13668250.2017.1293236.

19 Siobhán Burns and Mike Waite, "Building Resilience: A Pilot Study of an Art Therapy and Mindfulness Group in a Community Learning Disability Team," International Journal of Art Therapy 24, no. 2 (2019): 88-96, https://doi.org/10.1080/17454832.2018.1557228. 
to build the resilience of mentally disabled students through entrepreneurship programs. Here are some programs from "YAKUT" Special Schools Type C and C1 Purwokerto.

\section{Table 1. Entrepreneurial Type Program for "YAKUT" Special Schools Type C and C1 Purwokerto}

\begin{tabular}{|l|l|l|}
\hline Class & \multicolumn{1}{|c|}{ Type of Entrepreneur } & \multicolumn{1}{|c|}{$\begin{array}{c}\text { Entrepreneur Assistant } \\
\text { Teacher }\end{array}$} \\
\hline VII & Food (Typical Banyumas Snacks) & Sri Indarti, S.Pd \\
\hline VIII & Handicrafts (Bags, Floor mats, etc.) & $\begin{array}{l}\text { Khoridah Rosyad } \\
\text { Purbiningtyas, S.Pd }\end{array}$ \\
\hline IX & Food (Typical Banyumas Snacks) & Siti Djuwariyah, S.Pd \\
\hline X & Handicrafts (Bags, Floor mats, etc.) & Siti Marchamah, S.Pd \\
\hline XI & $\begin{array}{l}\text { Craft Arts (Painting, Drawing, } \\
\text { Photography) }\end{array}$ & Muhammad Saidi, S.Pd \\
\hline XII & Handicrafts (Bags, Floor mats, etc.) & Karina Purbiningtyas, S.Pd \\
\hline
\end{tabular}

This entrepreneurship program is a form of "YAKUT" Special School Type $\mathrm{C}$ and $\mathrm{C} 1$ Purwokerto to build transformations or experiences that change the lives of mentally disabled students. Siti Marchamah, S.Pd., stated that the transformation through the entrepreneurship program for "YAKUT" Special School Type C and C1 Purwokerto students was intended to build two aspects of transformation: personal transformation and relational transformation. Personal transformation continually means that mentally disabled students acquire new roles - in their families, communities, and careers. Their transformation also means acquiring new traits, such as speaking or finding new beliefs to build selfreliance. Students' relational transformation refers to how parents and students with mental retardation relate to other people.

Muhammad Saidi, S.Pd., Suryani, S.Pd as the coordinator of the Entrepreneurship Program at "YAKUT" Special School Type C and C1 Purwokerto, stated that the entrepreneurship program by "YAKUT" Special School Type C and C1 Purwokerto aims to help students stay competitive in the community through their role as an entrepreneur. Students are trained to be tough and adapt to their limitations. Students who have resilience are willing to work hard to achieve their goals, adapt to changes to take advantage of new situations, and learn from their mistakes. 
Resilience in students through entrepreneurship programs is the capacity students have to overcome difficult situations by becoming entrepreneurs. In this case, through the entrepreneurship program at "YAKUT" Special School Type C and C1 Purwokerto, students will develop self-resilience as a dynamic adaptation process that allows them to continue their future regardless of the destabilizing circumstances amid its limitations. The capacity for adaptation in the face of adversity depends on individual resources and their interaction with the environment. Therefore, it is reasonable to assume that students' resilience may change due to their efforts, which require them to adapt strategies and develop skills to face various situations with optimism and courage.

Resilience for mentally disabled students is the capacity of a dynamic system to adapt to the disturbances that threaten the system's function, survival, or development. This concept can be applied to various systems at various levels that interact with each other, both living and non-living, such as microorganisms, children, families, security systems, economies, forests, or the global climate. Interest in resilience as an observable concept and phenomenon emerged around the same time but independently in the field of ecology. ${ }^{20}$ The word resilience itself is rooted in the Latin verb resilire. Many disciplines have adopted this concept concerned with how well complex systems anticipate, adapt, recover, and learn in the context of major threats, surprises, and disasters.

Resilience refers to the human ability to adapt in the face of tragedy, trauma and other difficulties. ${ }^{21}$ Resilience is used to characterize individuals who can easily and quickly overcome setbacks related to their life and career aspirations. Resilience is an important quality for entrepreneurs. Resilience results from the interaction between entrepreneurs and their environment. ${ }^{22}$ Resilience is a dynamic and evolving process by which entrepreneurs acquire the knowledge, abilities and skills to help them face an uncertain future with a positive attitude, creativity and optimism and rely on their resources. Entrepreneurs are resilient when faced with adverse circumstances and can develop and mobilize resources they often do not expect to have. ${ }^{23}$ Resilience is a real growth strategy for "YAKUT" Special School

${ }^{20}$ Melody-Mackey, "Adverse Childhood Experiences, Special Education, and the Role of Resilience in the Life Course."

21 Scheffers, Moonen, and van Vugt, "External Sources Promoting Resilience in Adults with Intellectual Disabilities: A Systematic Literature Review."

22 Nikitha Harish et al., "Development of Vocational Potential Assessment Tool and Counseling Module for Persons with Severe Mental Disorders," Asian Journal of Psychiatry 47 (2020): 101866, https://doi. org/10.1016/j.ajp.2019.101866.

23 Eunra Kim and Jaekuk Park, "Structural Relationship among Disability Acceptance, Resilience, and 
Type C and C1 Purwokerto students. For students of "YAKUT" Special School Type $\mathrm{C}$ and $\mathrm{C} 1$ Purwokerto, resilience contains a multidimensional construction consisting of a network of encouraging attitudes and behaviours. Resilience is an amalgamation of various personal and behavioural qualities rather than a specific characteristic.

Resilience in the field of entrepreneurship for "YAKUT" Special School Type $\mathrm{C}$ and $\mathrm{C} 1$ Purwokerto students is thus considered an asset when faced with adversity and as a dynamic driving force strong enough to be considered a catalyst to initiate the entrepreneurial process itself. Drs. Rubimanto, M.Pd mentioned that certain events in the entrepreneurial process related to the context of an individual's life could lead them to make decisions to become entrepreneurs and take action. To better understand the socio-psychological factors linking displacement and the decision to become an entrepreneur, focusing on the resilience process can create a reference point to better place each move in an individual's life trajectory. Thus, "YAKUT" Special School Type C and C1 Purwokerto students can build society through entrepreneurs.

Kangogo mentions a link between resilience and entrepreneurship for students as a dynamic process of absorbing surprises that have been experienced, putting oneself back together, and generating meaning from experience. These elements are through interaction with one's environment, which is a supporter and helper of the dynamic itself. Next, we explore the role of these dynamics in triggering the decision to become an entrepreneur. ${ }^{24}$ However, on the other hand, Chadwick distinguishes three main stages of the entrepreneurial process, specifically, triggering the process, commitment or taking action, and the stage of survival/failure/development. ${ }^{25}$

"YAKUT" Special School Type C and C1 Purwokerto will mobilize students to try to make decisions that will be taken through the entrepreneurial program. This learning to become an entrepreneur is carried out to illuminate the first phase of the entrepreneurial process, especially when triggered, to understand better the dynamics that lead individuals to move to the active phase

Social Participation of Adolescents with Physical Disabilities," International Journal of Disability, Development and Education, 2021, 1-16, https://doi.org/1034912X.2021.1944610.

${ }^{24}$ Daniel Kangogo, Domenico Dentoni, and Jos Bijman, "Determinants of Farm Resilience to Climate Change: The Role of Farmer Entrepreneurship and Value Chain Collaborations," Sustainability 12, no. 3 (2020): 868, https://doi.org/doi.org/10.3390/su12030868.

25 Ingrid C Chadwick and Jana L Raver, "Psychological Resilience and Its Downstream Effects for Business Survival in Nascent Entrepreneurship," Entrepreneurship Theory and Practice 44, no. 2 (2020): 233-55, https://doi.org/10.1177/1042258718801597. 
of entrepreneurial development. This phase is carried out by investigating the role of resilience dynamics in triggering the decision to become an entrepreneur.

In Entrepreneurship, a collective work evokes the concept of resilience dynamics in a specific perspective of social inclusion and suggests a "theoretical meeting" between entrepreneurship and resilience dynamics. ${ }^{26}$ In addition, several researchers are interested in a narrative approach to studying the phenomenon of entrepreneurship, given the importance of the diachronic and synchronic dimensions of the entrepreneurial process.

The definition of various aspects of resilience of "YAKUT" Special School Type $\mathrm{C}$ and $\mathrm{C} 1$ Purwokerto students, as cognitive and emotional capacities, carries the key assumption that resilience consists of positive abilities: especially the ability to adapt the risky situations. Therefore, the concept of resilience is noticed as personality traits related to other positive traits, regardless of any context and dimensions associated with the process.

Resourcefulness refers to the resources, abilities, and skills that entrepreneurs have to control the various adverse situations they face. Resourcefulness implies that entrepreneurs believe in their ability to control circumstances and influence the outcomes of the situations they find themselves in. Another component of resilience is optimism. This component refers to the entrepreneur's capacity to maintain a positive attitude in challenging circumstances, where there is great uncertainty regarding the outcome. This component represents the entrepreneur's capacity to learn from mistakes and catch them as opportunities rather than failures.

The development of resourcefulness in students through entrepreneurial programs can be described significantly in resilience in students, where through entrepreneurial programs, students will (a) expand their cognitive and create judgments in such a way that stressors are seen as challenges that can be overcome (b) build their businesses more proactive, and thus (c) stay in business over time. Kangogo, in his article, mentions that it is important to adopt this well-established conceptualization of psychological resilience or resilience in the individual entrepreneurial process to build a more coherent body of literature with consistent definitions. ${ }^{27}$

${ }^{26}$ Reza Zadeh et al., "Effectiveness of Positive Psychology on Hope and Resilience in Mothers with Mentally Retarded Children."

27 Kangogo, Dentoni, and Bijman, "Determinants of Farm Resilience to Climate Change: The Role of Farmer Entrepreneurship and Value Chain Collaborations.” 
The entrepreneurship program at "YAKUT" Special School Type C and C1 Purwokerto is also intended to build positive emotions as the basis for individual psychological resilience. With psychological resilience, individuals are tough, and their optimism increases when they face challenges. Thus, tough "YAKUT" Special School Type C and C1 Purwokerto students better manage difficult situations because they cognitively perceive occurrences as challenges they can overcome rather than debilitating threats. Thus, the author emphasizes that resilience in entrepreneurship programs is an important resource for students to interpret and respond better amid their limitations. Students will engage in futuristic and adaptive behaviour through the entrepreneurship program.

Resilient entrepreneurs have a greater ability to renew themselves over time through innovation and adapt to changing environmental changes. ${ }^{28}$ Strong entrepreneurs have high self-esteem, feel in control and are not afraid to fail. Even in the face of adversity, if this happens, they "bounce back" stronger than before because they have learned from the situation. The experience of having made a mistake will create adaptation to their new circumstances and social environment.

\section{Conclusion}

The entrepreneurial program programmed by "YAKUT" Special School Type C and C1 Purwokerto aims to help students remain competitive in the community. Students are trained to be tough and adapt to their limitations. Students who have resilience are willing to work hard to achieve their goals, adapt to changes to take advantage of contemporary situations, and learn from their mistakes.

This research is relevant to the guidance and counselling disciplines for special-needs children. Thus, it will produce research and other scientific works that are beneficial for scientific development. The limitation of this research is only focused on the Entrepreneurship Program to increase the resilience of "YAKUT" Special School Type C and C1 Purwokerto students. Therefore, academics are expected to study with other methods (both qualitative and quantitative) and mixed methods with more in-depth studies that can be applied to the community regarding guidance and counselling disciplines for special-needs children. Other

28 Ángel Acevedo-Duque et al., "Resilience, Leadership and Female Entrepreneurship within the Context of Smes: Evidence from Latin America," Sustainability 13, no. 15 (2021): 8129, https://doi. org/10.3390/su13158129. 
research suggestions can also discuss sensory and motor development programs to create more interesting and unique research.

\section{Reference}

Acevedo-Duque, Ángel, Romel Gonzalez-Diaz, Elena Cachicatari Vargas, Anherys Paz-Marcano, Sheyla Muller-Pérez, Guido Salazar-Sepúlveda, Giulia Caruso, and Idiano D'Adamo. "Resilience, Leadership and Female Entrepreneurship within the Context of Smes: Evidence from Latin America." Sustainability 13, no. 15 (2021): 8129. https://doi.org/10.3390/ su13158129.

Albi, Anggito, and Johan Setiawan. "Metodologi Penelitian Kualitatif." Sukabumi: CV Jejak 245 (2018).

Azwar, Beni, Deri Wanto, and Rahmad Hidayat. "Improving Self-Resilience in Students with Special Needs through the Counseling Teachers' Roles: A Case Study on Grounded Theory." Education Research International 2021 (2021). https://doi.org/10.1155/2021/7872889.

Burns, Siobhán, and Mike Waite. "Building Resilience: A Pilot Study of an Art Therapy and Mindfulness Group in a Community Learning Disability Team." International Journal of Art Therapy 24, no. 2 (2019): 88-96. https:// doi.org/10.1080/17454832.2018.1557228.

Chadwick, Ingrid C, and Jana L Raver. "Psychological Resilience and Its Downstream Effects for Business Survival in Nascent Entrepreneurship." Entrepreneurship Theory and Practice 44, no. 2 (2020): 233-55. https://doi. org/10.1177/1042258718801597.

Djap, Wylen, Angaripeni Mustikasiwi, Oki Hermawati, Dadang Irawan, and Erwin Santosa. "The Resilience of Single Mothers with Special Needs Children in Supporting Their Education and Fulfilling Their Needs During The COVID-19 Pandemic." IJDS: Indonesian Journal of Disability Studies 8, no. 2 (2021): 425-41. https://doi.org/10.21776/ub.ijds.2021.008.02.10.

Fereidouni, Zhila, Amir Hossein Kamyab, Azizallah Dehghan, Zahra Khiyali, Arash Ziapour, Nafiul Mehedi, and Razie Toghroli. "A Comparative Study on the Quality of Life and Resilience of Mothers with Disabled and Neurotypically Developing Children in Iran." Heliyon 7, no. 6 (2021): e07285. https://doi.org/10.1016/j.heliyon.2021.e07285. 
García,Bibian Bibeca Bumbila,Hernán Andrés Cedeño Cedeño, Tatiana Katiuska Moreira Chica, and Yaritza Rossana Parrales Ríos. "Characterization of Auditory Disability and Its Relation to the Resilience." International Research Journal of Management, IT and Social Sciences 5, no. 2 (2018): 1522.

Ginevra, Maria Cristina, Ilaria Di Maggio, Sara Santilli, Teresa Maria Sgaramella, Laura Nota, and Salvatore Soresi. "Career Adaptability, Resilience, and Life Satisfaction: A Mediational Analysis in a Sample of Parents of Children with Mild Intellectual Disability." Journal of Intellectual \& Developmental Disability 43, no. 4 (2018): 473-82. https://doi.org/10.3109/13668250.20 17.1293236.

Harish, Nikitha, Aarti Jagannathan, Chennaveeraachari Naveen Kumar,Jagadisha Thirthalli, Santosh Kumar Chaturvedi, Devvarta Kumar, Poornima Bhola, Krishna Prasad Muliyala, Sivakumar Thanapal, and G Radhakrishnan. "Development of Vocational Potential Assessment Tool and Counseling Module for Persons with Severe Mental Disorders." Asian Journal of Psychiatry 47 (2020): 101866. https://doi.org/10.1016/j.ajp.2019.101866.

Joseph, Jonathan, and J Allister McGregor. Wellbeing, Resilience and Sustainability. Springer, 2019. https://doi.org/10.1007/978-3-030-32307-3_3.

Kangogo, Daniel, Domenico Dentoni, and Jos Bijman. "Determinants of Farm Resilience to Climate Change: The Role of Farmer Entrepreneurship and Value Chain Collaborations." Sustainability 12, no. 3 (2020): 868. https:// doi.org/doi.org/10.3390/su12030868.

Kim, Eunra, and Jaekuk Park. "Structural Relationship among Disability Acceptance, Resilience, and Social Participation of Adolescents with Physical Disabilities." International Journal of Disability, Development and Education, 2021, 1-16. https://doi.org/1034912X.2021.1944610.

Melody-Mackey, Lisa C. "Adverse Childhood Experiences, Special Education, and the Role of Resilience in the Life Course." Fielding Graduate University, 2021.

Mohan, Radhika, and Mrinmoyi Kulkarni. "Resilience in Parents of Children with Intellectual Disabilities." Psychology and Developing Societies 30, no. 1 (2018): 19-43. https://doi.org/10.1177/0971333617747321.

Rajan, Anugraha Merin, G Srikrishna, and J Romate. "Resilience and Locus of Control of Parents Having a Child with Intellectual Disability." Journal of 
Developmental and Physical Disabilities 30, no. 3 (2018): 297-306. https:// doi.org/10.1007/s10882-018-9586-0.

Reza Zadeh, Suneh, Anahita Khodabakhshi-Koolaee, Rahim Hamidy Pour, and Akram Sanagoo. "Effectiveness of Positive Psychology on Hope and Resilience in Mothers with Mentally Retarded Children." Iranian Journal of Psychiatric Nursing 6, no. 3 (2018): 32-38.

Sari, Putri Pranindita, and Yulia Ayriza. "The Relationship Of Parenting SelfEfficacy As A Predictor Of Resilience To Parents Of Children With Special Needs In Inclusive Schools." Advances In Social Science, Education And Humanities Research 296 (2019): 29-32.

Scheffers, Femke, Xavier Moonen, and Eveline van Vugt. "External Sources Promoting Resilience in Adults with Intellectual Disabilities: A Systematic Literature Review." Journal of Intellectual Disabilities, 2020, 1744629520961942. https://doi.org/10.1177/1744629520961942.

Zakariah, M Askari, Vivi Afriani, and K H M Zakariah. Metodologi Penelitian Kuantitatif, Kualitatif, Action Research, Research and Development $(R$ and $D)$. Yayasan Pondok Pesantren Al Mawaddah Warrahmah Kolaka, 2020. 
